\title{
Obstetric Anti-phospholipid Syndrome: State of the Art
}

\author{
Maria Chiara Gerardi ${ }^{1} \cdot$ Melissa Alexandre Fernandes ${ }^{2} \cdot$ Angela Tincani $^{1} \cdot$ Laura Andreoli $^{1}$
}

Published online: 13 August 2018

(C) Springer Science+Business Media, LLC, part of Springer Nature 2018

\begin{abstract}
Purpose of Review This review focuses on new pathogenesis and clinical-therapeutic aspects of obstetric anti-phospholipid syndrome (ob-APS) in the last 5 years.

Recent Findings The pathogenesis of ob-APS is multifactorial, including placental infarctions, infiltration of inflammatory cells that cause acute and chronic inflammation, leading to uncontrolled inflammation and poor pregnancy outcomes. A preconception counseling and a patient-tailored treatment are fundamental to improve maternal and fetal outcomes. Thanks to conventional treatment, based on low-dose aspirin and heparin, $70 \%$ of women with ob-APS can have successful pregnancies. Women with positive anti-phospholipid antibodies (aPL) without clinical manifestations ("aPL carriers") or with obstetric manifestation not fulfilling ob-APS criteria need to be further investigated in order to assess their best management.

Summary Great interest has been given to drugs that could interact in the pathophysiological mechanisms, such as hydroxychloroquine, statins, and eculizumab. These drugs could be considered for patients refractory to conventional therapy.
\end{abstract}

Keywords Anti-phospholipid syndrome · Anti-phospholipid antibodies · Pregnancy morbidity · Obstetric complications · Pathogenesis · Management · Treatment

\section{Introduction}

Anti-phospholipid syndrome (APS) is a systemic autoimmune disease characterized by arterial and/or venous thrombosis and/or obstetric morbidity mediated by anti-phospholipid antibodies (aPL). These pathogenic autoantibodies are determined by means of lupus anticoagulant (LA), IgM and $\operatorname{IgG}$ anti-cardiolipin (aCL), and anti- $\beta 2$ glycoprotein-I (aß2GPI) antibodies; their presence should be confirmed in two different occasions at least 12 weeks apart [1].

Even though the syndrome was initially described as a single disorder, the distinction between obstetric (ob-

This article is part of the Topical Collection on Antiphospholipid Syndrome

\section{Laura Andreoli}

laura.andreoli@unibs.it

1 Rheumatology and Clinical Immunology Unit and Department of Clinical and Experimental Sciences, Spedali Civili and University of Brescia, Brescia, Italy

2 Autoimmune Disease Unit—Department of Internal Medicine, Hospital Curry Cabral/Centro Hospitalar Lisboa Central, Lisbon, Portugal
APS) and thrombotic APS has been well established during the last 10 years given the following observations: (1) patients can display vascular thrombosis with no pregnancy complications or, alternatively, obstetric manifestations alone [2]; (2) the coexistence of both thrombosis and miscarriages only affects about $2.5-5 \%$ of APS pregnancies [3]; (3) IgG fractions from pure ob-APS display different effects in vitro on monocyte and trophoblast cells [4].

The ob-APS can affect both the mother and the fetus [5]. The clinical criteria of ob-APS were revised in 2006, as follows: history of three early consecutive miscarriages $(<10$ weeks of gestation, with maternal anatomic or hormonal abnormalities and paternal and maternal chromosomal causes excluded), and/or one stillbirth ( $>10$ weeks of gestation, with normal fetal morphology documented by ultrasound or by direct examination of the fetus), and/or one intra-uterine growth restriction (IUGR) or a premature birth before 34 weeks of gestation due to preeclampsia (PE) or eclampsia or placental insufficiency (abnormal or non-reassuring fetal surveillance test, abnormal Doppler flow velocimetry waveform analysis suggestive of fetal hypoxemia, oligohydramnios, and postnatal birth weight less than the 10th percentile for the gestational age) [1]. Furthermore, pregnant women with ob-APS have an increased risk of thrombosis [5], 
thrombocytopenia, and HELLP syndrome (hemolytic anemia, elevated liver enzymes, and low platelet count) [6].

This narrative review summarizes the latest research on pathological, clinical, and therapeutically aspects of ob-APS.

\section{Epidemiology}

APS can occur as an isolated disease (primary) or associated with other systemic autoimmune diseases (secondary), mainly with systemic lupus erythematosus (SLE). Robust epidemiological data from large controlled population studies are still lacking. Women are more commonly affected by APS than men, in primary (3.5:1 ratio) as well as in secondary APS (7:1) [7].

According to the review of the literature, aPL are positive in approximately $6 \%$ of women with pregnancy morbidities (pregnancy losses, IUGR, PE/eclampsia, and HELLP syndrome) [8].

\section{Pathogenesis}

The exact mechanisms involved in the prothrombotic state of the disease (causing thrombosis and/or obstetric complications) remain yet to be fully explained. aPL have the ability to induce thrombus formation in the arterial and/ or venous vasculature and/or microcirculation by targeting and affecting the functionality of a variety of cell types such as endothelial cells, monocytes, leukocytes, neutrophils, and platelets on the vascular aspect of the disease, and trophoblasts and decidual cells during gestation; the irregular function of these cells contributes in the disease development [9]. Several studies have reported that aPLs have the capacity to interact with the trophoblast and the endothelial cell monolayer, by disrupting the anticoagulant annexin A5 shield, resulting in fetal loss [10].

However, De Wolf et al. and Stone et al., in histopathologic findings in the human placenta samples, have demonstrated that other non-thrombotic mechanisms, such as inflammation, may be involved in the pathogenesis of ob-APS, besides placental infarctions $[11,12]$ (Table 1). Viall et al., in a recent meta-analysis of the histopathologic findings in the placentae from aPL-affected pregnancies, revealed five features associated with aPL: (1) placental infarction, (2) impaired spiral artery remodeling, (3) decidual inflammation, (4) increased syncytial knots, and (5) decreased vasculosyncytial membranes [36].

Table 1 Pathogenic mechanisms of ob-APS

\begin{tabular}{|c|c|c|}
\hline & Pathogenic mechanism & References \\
\hline \multirow[t]{7}{*}{ Thrombosis } & $\begin{array}{l}\text { In vitro models: } \\
\text { - aPL interact with endothelial cells, predominately by binding to } \beta_{2} \text { GPI expressed on the cell membranes of different cell types, } \\
\text { and induces a procoagulant and pro-inflammatory endothelial state }\end{array}$ & {$[13]$} \\
\hline & $\begin{array}{l}\text { - aPL upregulate TF expression on endothelial cells and blood monocytes, as well as, by promoting endothelial leukocyte } \\
\text { adhesion, cytokine secretion and PGE2 synthesis }\end{array}$ & [14-17] \\
\hline & $\begin{array}{l}\text { - aPL recognize phospholipid-binding proteins expressed on platelets and induces platelet aggregation induced by another } \\
\text { agonist }\end{array}$ & {$[18,19]$} \\
\hline & $\begin{array}{l}\text { - aPL interferes with plasma components of the coagulation cascade by inhibiting anticoagulant activity, reducing fibrinolysis, } \\
\text { and disrupting annexin A5 shield of the trophoblast and endothelial cell monolayers }\end{array}$ & $\begin{array}{l}{[13,18,20,} \\
21]\end{array}$ \\
\hline & In vivo models: & \\
\hline & $\begin{array}{l}\text { - infusion of aPL with or without } \beta 2 \mathrm{GPI} \text { alters expression of endothelial adhesion molecules, causing upregulation of NO and } \\
\mathrm{TF} \text { expression causes vascular abnormalities (especially in the arterial endothelium) }\end{array}$ & \\
\hline & $\begin{array}{l}\text { - Thrombotic effects were produced using affinity-purified anti- } \beta_{2} \text { GPI IgG, and were inhibited by specific absorption of } \\
\text { anti- } \beta_{2} \text { GPI activity }\end{array}$ & {$[22,23]$} \\
\hline \multirow[t]{8}{*}{ Inflammation } & In vitro models: & {$[24]$} \\
\hline & - aPL, via TLR-4 and MyD88, induce trophoblasts to secrete IL-1 $\beta$ and IL-8 & \\
\hline & $\begin{array}{l}\text { - Downstream of MyD88, IL-1 } \beta \text { secretion is mediated by uric acid, which in turn activates NLRP3 inflammasome to process } \\
\text { IL-1 } \beta\end{array}$ & {$[25]$} \\
\hline & $\begin{array}{l}\text { - Trophoblast inflammation is driven by aPL induced miR-146a-3p and uric acid which activate TLR- } 8 \text { and the NLRP3 } \\
\text { inflammasome in trophoblasts }\end{array}$ & {$[26]$} \\
\hline & $\begin{array}{l}\text { - Decidual stromal cells treated with a } \beta 2 \mathrm{GPI}-\text { dependent aPL monoclonal antibody, express an upregulation of genes involved } \\
\text { in the inflammatory response }\end{array}$ & {$[27,28]$} \\
\hline & In vivo models: & {$[29-31]$} \\
\hline & $\begin{array}{l}\text { - aPL located in the placenta and inflammation (by complement activation and recruitment and stimulation of neutrophils is the } \\
\text { main factor in placental insufficiency, fetal loss, and IUGR) }\end{array}$ & \\
\hline & - $\mathrm{C} 5$ is the key effector and acts through the upregulated expression of TF on neutrophils infiltrating placental tissues & \\
\hline \multirow{3}{*}{$\begin{array}{l}\text { Complement } \\
\text { activation }\end{array}$} & In vivo models: & {$[22,32-34]$} \\
\hline & $\begin{array}{l}\text { - Animals deficient in complement components or complement receptors, or treated with complement inhibitors were protected } \\
\text { from thrombogenic effect of aPL }\end{array}$ & \\
\hline & - Complement deposition was found in placenta tissue from women positive for aPL, in retrospective study & [35] \\
\hline
\end{tabular}

$a P L$ anti-phospholipid antibodies, $L A A$ low avidity autoantibodies, $\beta_{2} G P I \beta_{2}$ glicoprotein I, NO nitric oxide, $T F$ tissue factor, $I L$ interleukin, $T L R$ tolllike receptor, $M y D 88$ myeloid differentiation factor $88, m i R$ microRNA 
aPL recognizing $\beta 2$ GPI have been shown to be pathogenic in ob-APS due to its constant expression on the cell surface [10]. The placenta is a major target for $\beta 2 \mathrm{GPI}$-dependent pathogenic aPL binding and consequently reducing trophoblast differentiation/invasiveness [10]. This was demonstrated by 14 studies that investigated trophoblast invasion in the presence of aPL in vitro. Both the outer placental syncytiotrophoblast (STB) and the extravillous trophoblast (EVT) bind to a 32 GPI antibodies differently; the STB internalized aPL via a low-density lipoprotein receptor (LDLR), and the EVT maintains aPL on the cell surface [37••, 38].

During the first trimester, if maternal spiral arteries are not sufficiently plugged by endovascular trophoblasts, then strong stream of blood from the arteries may physically or oxidatively damage the placenta and contribute to early pregnancy loss [39]. As gestation progresses, if trophoblasts do not transform the maternal spiral arteries into wide-bore tubes adapted for efficient blood flow, the placenta may become hypoperfused and undergo ischemia-reperfusion injury, leading to PE and IUGR [40].

In vitro studies, using human first-trimester EVT, demonstrated that aPL recognizing $\beta 2 \mathrm{GPI}$ trigger EVT to produce elevated levels of pro-inflammatory cytokines and chemokines, inhibit spontaneous trophoblast migration, increase trophoblast antiangiogenic soluble endoglin secretion, and disrupt trophoblast-endothelial interactions in a model of spiral artery transformation, reproducing similar changes to those in PE [41, 42].

Two in vitro studies demonstrated that aPL induce trophoblasts inflammation by secreting interleukin-1 $\beta$ (IL-1 $\beta$ ) and IL-8 via activation of Toll-like receptor 4 (TLR-4) and its adapter protein myeloid differentiation factor 88 (My88) [24, 25]. Downstream of My 88 and IL- $1 \beta$ is mediated by uric acid which activates NLRP3 inflammasome to process IL- $1 \beta$ and IL-8 production; downstream of TLR-4 is mediated by induction of microRNA-146a-3p (miR 146a-3p). aPL-induced miR-146a-3p and uric acid act as endogenous secondary signals for activation of TLR-8 and NLRP3 inflammasome in trophoblasts, to drive trophoblast inflammation [43]. A recent in vitro study demonstrated that a $32 \mathrm{GPI}$ aPL induce altered TAM receptor signaling (negative regulator of TLR) and autophagy causing, respectively, subsequent TLR4-mediated IL-8 response and NLRP3 inflammasome-mediated IL-1 activity leading to a robust inflammatory response [44•].

Reduced trophoblast migration and invasion caused by aPL are mediated by apolipoprotein E receptor 2 (ApoER2) which interacts with dimerized $\beta 2$ GPI. ApoER2 serves as a target for anti- $\beta 2$ GPI- $\beta 2$ GPI complexes leading to reduced pro-migratory IL-6 and STAT-3 activity. In vivo studies have demonstrated the role of ApoER2 in aPL-mediated feta loss and IUGR [27].

However, there seems to be a difference between the pathogenesis of aPL-related recurrent pre-embryonic loss and late pregnancy morbidity. Especially for early pregnancy losses, the effects of aPL on placentation may be relevant, as these autoantibodies increase apoptosis and reduce invasion of the trophoblast [45]. The complement system, instead, seems to play a crucial role in causing pregnancy loss and fetal growth restriction. Shamonki et al, in human studies, showed that placenta of women with aPL has increased complement deposition of $\mathrm{C} 4 \mathrm{~d}$ and $\mathrm{C} 3 \mathrm{~b}$, supporting the hypothesis that complement activation is involved in the pathogenesis of aPL-related pregnancy complications $[35,36]$. Inherited hypofunctional variants of complement regulators provide an increased risk of PE in women with SLE and/or aPL [46]. A recent study in pregnant patients with SLE and/or aPL, increased levels of $\mathrm{Bb}$ and sC5b-9, complement activation products, early in pregnancy were significantly associated with adverse pregnancy outcomes (APOs) $[47 \bullet]$.

A mediator that plays an important role in the complement activation is the tumor necrosis factor (TNF). This mediator links complement C5a-C5aR interactions and pathogenic aPL to fetal damage [48]. aPL that target decidual tissue cause a rapid increase in decidual and systemic TNF levels. Studies on mice have suggested that miscarriages induced by aPL are less frequent in those who are deficient in TNF or treated with TNF blockade. In humans, TNF contributes to the pathogenesis of poor pregnancy outcomes: TNF- $\alpha$ increases throughout pregnancy and has been related to miscarriages, fetal losses, PE, and preterm birth as well as IL-10 reduction [49].

As described above, placental infarction due to thrombus occluding spiral artery is a common histopathologic finding in ob-APS. In two studies that examined the placentae from first trimester abortions, placental thrombotic infarction or spiral artery thrombosis were not detected, this suggests that this phenomenon could be associated with late pregnancy complications $[50,51]$.

Another factor that also plays an important role in the pathogenesis of PE in SLE patients is Interferon (IFN) $\alpha$. In vitro and in vivo studies suggest that elevated IFN- $\alpha$ levels contribute in developing PE by sensitizing maternal endothelium to the antiangiogenic effects of soluble Flt-1 and by inhibiting transcription of proangiogenic VEGF, necessary for homeostasis in some vascular beds. Increased IFN- $\alpha$ levels may identify SLE patients who have an increased risk of developing placenta-mediated pregnancy complications; this may be related to the vasculopathic effects of elevated IFN $\alpha$ in active SLE patients who experience PE early in pregnancy [52].

\section{Predictive Factors of Obstetrical Outcome}

Risk factors associated with adverse pregnancy outcomes include: high number of previous pregnancy losses [53], thrombotic APS [54, 55], associated autoimmune diseases (SLE) 
[56], hypocomplementemia at conception $[57,58,59 \bullet]$, high antibody titer [60,61], and the number and the type (LAC and $\mathrm{IgG} \mathrm{aCL}$ ) of different autoantibodies detected, with an increased risk in patients with a triple-positive profile $[55,61$, $62]$. The presence of triple aPL positivity seems to be due to antibodies directed to the first domain of $\beta 2$ GPI, anti-D1 [63, 64]. These pathogenic antibodies are more frequent in patients having higher antibody titers and triple positivity for aPL. This seems to make sense because these pathogenic antibodies have LA activity [65]. On the other hand, single positivity for the aPL profile seems to be associated with positive tests for anti-domain $4 / 5$, considering these are non-pathogenic antibodies [66]. Interestingly, it has been recently demonstrated that anti-D1 are significantly associated with pregnancy morbidity, in particular late pregnancy morbidity (late pregnancy losses and premature delivery) [67•]. Data from the study PROMISSE showed that LA was the only aPL associated with APOs after the first trimester [68].

As for the antibody titer, conflicting results exist. Even though high positive antibody titers are associated with adverse pregnancy outcome $[60,61]$, there is increasing evidence that patients with low-titer aPL can experience poor pregnancy outcomes similarly to high-titer aPL patients [69-73]. These observations suggest that in contrast to thrombotic events, low-titer aPL can play a significant role in obAPS and that the current classification criteria may not allow to include all the ob-APS cases.

Future prospective studies with homogeneous study population and design are needed to clarify these findings and to identify additional risk factors and better delineate the optimal personalized risk-based management of these women.

\section{Clinical Manifestations}

The frequency of obstetric complications varies among studies and depends on the selected APS phenotype and on the treatment regimen [74]. The rates of PE range from 2 to $17 \%$, venous thrombosis $2-3 \%$, IUGR $3-12 \%$, preterm delivery $11-19 \%$, hypotrophy $11-23 \%$, and neonatal complications $11-13 \%[75,76]$. In the PROMISSE study, Lockshin et al. reported an overall APO of $19 \%$ after exclusion of early pregnancy loss [76].

In a multicenter prospective study, the Euro-Phospholipid project, 1000 APS European patients were followed during a 10 -year period [77 ••]. A total of 188 pregnancies occurred in 127 women and $72.9 \%(n=137)$ of pregnancies succeeded in having one or more live births. The most common obstetric complication was early pregnancy loss $(<10$ weeks $)$ in $16.5 \%$ $(n=31)$ of pregnancies. The obstetric morbidity rate was lower during the last 5 years of the study; no women developed PE/eclampsia. Regarding fetal morbidity, the most frequent manifestations were birth prematurity ( $48.2 \%$ of the total live birth) and IUGR (26.3\%) [77••]. In a European cohort of 247 ob-APS (EUROAPS), live births were achieved in 192/247 cases $(77.7 \%)$. Of these 192 successful cases, 174 (89.7\%) received treatment and $18(10.3 \%)$ did not. Obstetric complications appeared in 129/247 (52.2\%) cases, although not all ended in fetal demise or stillbirth. Fetal loss was the most frequent fatal complication (17.80\%) followed by miscarriage (16.27\%), with stillbirth being relatively infrequent $(4.69 \%)$. Prematurity was the most common non-fatal complication (47.28\%). Early and severe PE together with HELLP syndrome appeared in more than $18 \%$ of these women. IUGR complicated $15.50 \%$ of cases [78]. Patients with ob-APS mainly suffer from obstetrical morbidity, but the risk of thrombotic events persists during the follow-up $[5,78,79]$.

\section{Management of ob-APS}

\section{General Considerations}

The management of women with ob-APS includes a close surveillance and tailored treatment before, during, and after pregnancy to optimize maternal and fetal pregnancy outcomes.

As stated in the EULAR recommendations [80••], a preconception counseling is fundamental to assess any previous pregnancy complications and/or thrombotic events, the presence of the "APS non-criteria manifestations" [80••], other associated autoimmune diseases (SLE), genetic thrombotic risk factors, major organ involvement, the presence of other comorbidities, life style risk factors (e.g., smoking, alcohol consumption), medications that may compromise fetal development, and the risk stratification according the aPL profile (Table 2).

Thanks to counseling and risk stratification assessment, it is possible to set up preventive strategies and a patient-tailored monitoring plan. If possible, visits and blood tests should be performed monthly, although a less tight schedule can be planned for low-risk patients. In addition to the routine first and second ultrasonography screening, patients with ob-APS should undergo supplementary surveillance in the third trimester, at monthly intervals, based on biometric and Doppler findings, in order to diagnose an early or late IUGR and plan the time of delivery [80••]. In patients with current or past renal involvement, blood pressure and 24-h urine proteinuria should be regularly monitored.

\section{Obstetric APS}

Current standard of care for women with ob-APS includes prophylactic or therapeutic dose of heparin (unfractionated heparin-UFH- or low-molecular weight heparin-LMWH) combined with low dose of aspirin (LDA) (75-100 mg/day) 
Table 2 Suggested management of obstetric-APS

Management

General measures

"Criteria" ob-APS

Refractory ob-APS

(with previous pregnancy failure on conventional treatment)

APS patients with previous thrombosis

CAPS, during pregnancy

APS associated to autoimmune diseases (e.g., SLE)

aPL carriers or women not fulfilling clinical criteria for ob-APS

"Low-risk"\# aPL profile

•"High-risk"\# aPL profile and/or additional risk factors and/or APS non-criteria manifestations
Folic acid preferably for at least 3 months prior to conception and throughout pregnancy Calcium and vitamin D during pregnancy

During puerperium, prevent immobility and use compression stockings if history of thrombosis

Pregnancy Conventional treatment:

$\mathrm{LDA}^{\mathrm{a}) \square}\left(75-100 \mathrm{mg} /\right.$ day) plus prophylactic $\mathrm{LMWH}^{\square}$ or $\mathrm{UFH}^{\square}$

$\mathrm{LDA}^{\mathrm{a}) \square}\left(75-100 \mathrm{mg} /\right.$ day) plus prophylactic/therapeutic $\mathrm{LMWH}^{\square}$ or $\mathrm{UFH}^{\square}$ and consider one or more of the following additional treatments:

- Prednisolone $(10 \mathrm{mg} / \mathrm{day})$ in the first trimester $(0-14$ weeks of gestation)

- IVIG $(400 \mathrm{mg} / \mathrm{kg} /$ day for 5 consecutive days or $1 \mathrm{~g} / \mathrm{kg}$ daily for 2 consecutive days

- Plasmapheresis ( 3 to 5 consecutive days)

- HCQ (5-6 mg/kg/day)

- Pravastatin ( $20 \mathrm{mg} /$ day)

Puerperium Prophylactic LMWH ${ }^{\square}$ or $\mathrm{UFH}^{\square}$ for 4-6 weeks

Pregnancy Stop VKA ${ }^{\square}$ (before the sixth week of gestation)**

start $\mathrm{LDA}^{\mathrm{a})}\left(75-100 \mathrm{mg} /\right.$ day) plus therapeutic $\mathrm{UFH}^{\square}$ or $\mathrm{LMWH}^{\square}$

Puerperium Therapeutic UFH or LMWH

OR

VKA**

First-line therapy

$\mathrm{UFH}^{* \square}$ (80 U/kg IV bolus) then continuous infusion of $18 \mathrm{U} / \mathrm{kg} / \mathrm{h}$

Glucocorticoids methylprednisolone (IV)

$500-1000 \mathrm{mg} /$ day for 1 to 3 days

and

slowly reduce to $1-0.5 \mathrm{mg} / \mathrm{kg} / \mathrm{day}$

(depending on clinical condition)

Plasmapheresis (three to 5 consecutive days)

and/or

IVIG (2 schemes, after plasmapheresis)

$400 \mathrm{mg} / \mathrm{kg} /$ day for 5 consecutive days

or

$1 \mathrm{~g} / \mathrm{kg} / \mathrm{month}$

Second-line therapy

RTX [375 mg/m² (IV) $1 /$ week during 1 month or $1 \mathrm{~g}$ twice 15 days apart] or

Eculizumab [900 mg (IV)/week for 4 weeks then $1200 \mathrm{mg} / 2$ weeks]

Pregnancy $\quad$ LDA $^{\text {a) }}\left(75-100 \mathrm{mg} /\right.$ day) plus prophylactic/therapeutic $\mathrm{LMWH}^{\square}$ or $\mathrm{UFH}^{\square}$ (prophylactic/therapeutic weight-adjusted dose depending the main clinical manifestation of APS, thrombotic or obstetric) and

HCQ $(5-6 \mathrm{mg} / \mathrm{kg} /$ day $)$

Puerperium Prophylactic UFH or LMWH for 4-6 weeks

Pregnancy

$\operatorname{LDA}^{\text {a) }}(75-100 \mathrm{mg} /$ day $)$

LDA $^{\text {a) }}$ (75-100 mg/day) plus UFH ${ }^{\square}$ or LMWH ${ }^{\square}$ (prophylactic weight-adjusted dose depending on aPL profile plus concomitant risk factors and/or additional APS non-criteria manifestations)

According to individual risk stratification, consider adding HCQ 5-6 kg/day

Puerperium Prophylactic UFH ${ }^{\square}$ or $\mathrm{LMWH}^{\square}$ for 4-6 weeks

$a P L$ anti-phospholipid antibodies, $A P S$ anti-phospholipid syndrome, $C A P S$ catastrophic anti-phospholipid syndrome, $I V$ intravenous, $I V I G$ intravenous immunoglobulins, $o b-A P S$ obstetric-anti-phospholipid syndrome, $R T X$ rituximab, UFH unfractionated heparin, $U$ units, $L M W H$ low molecular weight heparin, $k g$ kilogram, $h r$ hour, $m g$ milligram

\# "low-risk" profile (patients with isolated, intermittently positive aCL, or aß2GPI at low-medium titers); "high-risk" aPL profile: LA positivity, or "triple positivity"- LA + aCL + a $32 \mathrm{GPI}$ - or medium-high titers of IgG aCL or IgG aß2GPI

* Acute phase

** Warfarin: teratogenic, especially between the 6 th and 10 th week of gestation; risk of fetal bleeding specially after the 32th week of gestation. During puerperium, it can be restarted after bridging therapy with heparin

a) Depending on formulations of the drug available in different countries

LDA should be started prior to conception and stopped before delivery depending on the local protocol. Heparin should be started when pregnancy is confirmed (at positive pregnancy test or after ultrasound confirmation, depending on local protocols) and stopped before delivery depending on the type of heparin and the mode of delivery

$\square$ In pregnant women with APS and thrombocytopenia, a frequent APS non-criteria manifestation, the use of heparin, LDA, and VKA should be carefully evaluated due to the increased risk of bleeding. If thrombocytopenia is mild, above $50 \times 10^{9} / \mathrm{L}$, and no signs of bleeding, anti-thrombotic treatment can be continued. If platelet count is below $50 \times 10^{9} / \mathrm{L}$, the use of anti-thrombotic drugs should be weighed against the risk of clotting 
$[80 \bullet, 81]$. The LDA should be preferably given prior to conception, and LMWH or UFH treatment should begin as soon as pregnancy is confirmed. It has been demonstrated that both UFH plus LDA and LMWH plus LDA are effective in the management of recurrent abortion secondary to APS [82-84]. Given the similar efficacy with both types of heparin, LMWH could be preferred for practical reasons due to its route of administration and no need for monitoring and for its lower risk of osteoporosis [85]. Regarding the dosage of prophylactic heparin, it is unknown if fixed doses are equal or more efficacious than adjusted ones in preventing APOs. Just one prospective study showed that weight-adjusted, once daily, doses of LMWH combined with LDA could be an efficacious treatment option for pregnant APS patients with no history of thrombosis [56]. However, in clinical practice, most physicians use a fixed dosage of LMWH in pregnant APS.

In ob-APS patients with higher risk to develop a first thrombotic event, due to the "high-risk" aPL profile and concomitant risk factors and/or additional "APS non-criteria manifestations," therapeutic dose of heparin should be preferred $[80 \bullet \cdot$.

\section{Refractory Obstetric APS}

However, current management does not prevent all maternal, fetal, and neonatal complications of APS, and the current treatment fails in 20 to $30 \%$ of APS pregnancies, raising the need to explore other treatments to improve obstetrical outcome. In these women with refractory ob-APS, treatment options to improve pregnancy outcomes include prednisolone (10 mg/day, 0-14 weeks) and/or intravenous immunoglobulin (IVIG) and/or plasmapheresis [86, 87•]. Great interest has been given to drugs that could interact in the pathophysiological mechanisms of the disease, such as hydroxychloroquine (HCQ), statins, and certolizumab pegol (CTZ). As for HCQ, a group of experts recommended HCQ in addition to conventional treatment in those with APS and with previous pregnancy failure on current treatment [88]. Furthermore, an international task force highlighted the need for clinical trials of HCQ in pregnant women with aPL and APS [89]. In vitro studies suggested that HCQ inhibits aPL binding to trophoblasts restoring their function [90]; in a recent mouse model of ob-APS, HCQ at a dose similar to the therapeutic dose in human, prevented fetal death even the ex vivo gamma counting, and immunohistochemical analysis did not affect the aPL binding to the placenta [91•]. Three retrospective studies have showed the benefits of HCQ in improving APOs in APS patients in addition to conventional treatment [92-94]. In a recent multicenter retrospective study, high HCQ $(400 \mathrm{mg} /$ day $)$ versus low HCQ $(200 \mathrm{mg} /$ day $)$ and its administration before versus during pregnancy was associated with a significantly higher live birth rate in APS patients without previous thrombosis [87•]. The HYPATIA study, a multicenter randomized clinical trial (RCT), will start in the near future. This will evaluate the efficacy of HCQ versus placebo in addition to standard of care in women with persistent aPL planning for pregnancy [95]. The HYDROSAPL, a French RCT, will assess the efficacy of the addition of HCQ to conventional treatment during pregnancy in ob-APS and thrombotic APS [96] (Table 3).

Due to the similarities in pathophysiology among PE, IUGR, and atherosclerotic cardiovascular disease, statins have been proposed for treating and/or preventing these obstetrical complications. Lefkou et al. reported on a small, observational trial that showed a dramatic improvement in both maternal and fetal/neonatal outcomes in women with APS given pravastatin $(20 \mathrm{mg} /$ day) in addition to LDA and heparin after the onset of PE and/or IUGR compared with women in the control group on conventional treatment [97•]. The protective effects of pravastatin on the endothelium together with its effect in restoring angiogenic balance might explain the amelioration of placental and maternal preeclamptic signs. Keeping in mind the potential role of TNF in the development of obstetric complications, an ongoing trial, the Improve Pregnancy in APS with Certolizumab Therapy (IMPACT) study is evaluating if CTZ, a TNF inhibitor that does not cross the placenta [98], reduces the risk of APOs in high-risk APS patients [99] (Table 3).

\section{Thrombotic and Obstetric APS}

In ob-APS women with a history of a previous thrombotic event, the treatment is based on secondary thromboprophylaxis by using anti-thrombotic drugs and preventive strategies to minimize the risk of recurrent thrombosis and reduce APOs [100]. Since APS women with a previous thrombosis are usually treated with anticoagulation therapy, particularly with vitamin $\mathrm{K}$ antagonist (VKA), it is important for these women to discontinue VKA and switch to therapeutic LMWH and LDA $[101,102]$, as soon as pregnancy is confirmed in order to avoid fetal warfarin syndrome [103, 104], as a consequence of the exposure to warfarin between the 6th and 12th gestational week. In some countries (e.g., Brazil), the use of VKA is considered from the 13th week until the 36th week of gestation [105], because of the impracticability of LMWH due to its cost.

\section{Antithrombotic Management During the Delivery Period}

Another important aspect is the management of antithrombotic and anti-platelet medications in these women during delivery and the puerperium period. Even though the time to stop treatment remains controversial, this depends mostly on local protocols and the type of delivery programmed by the obstetrician. Discontinuation of LDA depends on the centers anesthesiologist experience and implemented hospital protocol. It is recommended that patients on anticoagulation with 
Table 3 Human studies evaluating novel therapies in ob-APS

\begin{tabular}{|c|c|c|c|c|}
\hline Drug & $\begin{array}{l}\text { Study, } \\
\text { year }\end{array}$ & Type of study & Population $(n)$ & Main findings \\
\hline \multirow[t]{6}{*}{ HCQ } & $\begin{array}{l}\text { Mekinian A et } \\
\text { al., } 2015\end{array}$ & $\begin{array}{l}\text { Observational } \\
\text { retrospective }\end{array}$ & APS [49] with 35 pregnancies & $\begin{array}{l}\text { LDA + LMWH vs HCQ + LDA + LMWH: } \\
\text { significant decrease of PrL from } 81 \text { to } 19 \%\end{array}$ \\
\hline & $\begin{array}{l}\text { Sciascia S et al., } \\
2016\end{array}$ & $\begin{array}{l}\text { Observational } \\
\text { retrospective }\end{array}$ & $\begin{array}{l}98 \text { aPL-positive women with } 174 \\
\text { pregnancies } \\
(51 \text { HCQ + LDA + LMWH vs } 119 \text { LDA } \\
\text { + LMWH })\end{array}$ & $\begin{array}{l}\mathrm{HCQ}+\mathrm{LDA}+\mathrm{LMWH} \text { : higher rate of live births } \\
\text { and a lower prevalence of overall pregnancy morbidity }\end{array}$ \\
\hline & $\begin{array}{l}\text { Ye SL et al., } \\
2017\end{array}$ & $\begin{array}{l}\text { Observational } \\
\text { retrospective }\end{array}$ & 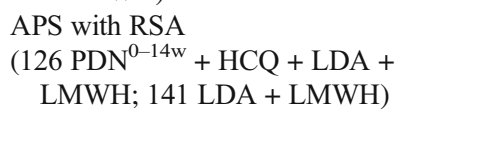 & $\begin{array}{l}\text { PDN + HCQ + LDA + LMWH: decrease in the incidence of } \\
\text { repeat PrL, miscarriage, and placental dysfunction-related } \\
\text { diseases and a significant increase in pregnancies lasting } \\
\text { longer than } 24 \mathrm{w}\end{array}$ \\
\hline & $\begin{array}{l}\text { Ruffatti et al., } \\
2018\end{array}$ & $\begin{array}{l}\text { Observational } \\
\text { retrospective }\end{array}$ & Pregnant APS patients (194) & $\begin{array}{l}\text { HCQ } 400^{\mathrm{mg}} \text { vs } 200^{\mathrm{mg}} \text {, HCQ before vs during pregnancy: } \\
\text { significant increase in the live birth rate }\end{array}$ \\
\hline & $\begin{array}{r}\text { HYPATIA, } \\
\text { ongoing }\end{array}$ & $\begin{array}{l}\text { Double-blind } \\
\text { RCT }\end{array}$ & $\begin{array}{l}\text { aPL carriers and APS women who are } \\
\text { planning pregnancy (target sample } \\
\text { size: } 328 \text { ) }\end{array}$ & $\begin{array}{l}\text { HCQ + LDA-LMWH vs placebo + LDA + LMWH. } \\
\text { Endpoint: rate of APOs }\end{array}$ \\
\hline & $\begin{array}{l}\text { HYDROSAPL } \\
\text { ongoing }\end{array}$ & $\begin{array}{l}\text { Double-blind } \\
\text { RCT }\end{array}$ & $\begin{array}{l}\text { ob-APS and t-APS during pregnancy } \\
\text { (target sample size: } 220 \text { ) }\end{array}$ & $\begin{array}{l}\text { HCQ + LDA-LMWH vs placebo + LDA + LMWH. } \\
\text { Endpoint: rate of uncomplicated pregnancy }\end{array}$ \\
\hline Pravastatin & $\begin{array}{l}\text { Lefkou E et al., } \\
\quad 2016\end{array}$ & Retrospective & $\begin{array}{l}\text { ob-APS with PE and/or IUGR } \\
(11 \text { pravastin + LDA + LMWH vs } 10 \\
\text { LDA + LMWH) }\end{array}$ & $\begin{array}{l}\text { Pravastatin }(20 \mathrm{mg} / \mathrm{d})+\mathrm{LDA}+\mathrm{LMWH} \text { : increased placental } \\
\text { blood flow and improvements in PE features }\end{array}$ \\
\hline Eculizumab & $\begin{array}{l}\text { Gustavsen A et } \\
\quad \text { al., } 2017\end{array}$ & Case report & $\begin{array}{l}\text { An APS pregnant woman with previous } \\
\text { arterial thrombosis and ongoing leg } \\
\text { ischemia }\end{array}$ & $\begin{array}{l}\text { Two dose of eculizumab } \\
\text { ( } 600 \mathrm{mg} 8 \text { and } 1 \text { day) before delivery: ischemic symptoms } \\
\text { declined following the } 1 \text { st dose and no adverse effects } \\
\text { were seen. }\end{array}$ \\
\hline $\mathrm{CTZ}$ & $\begin{array}{l}\text { IMPACT, } \\
\text { ongoing }\end{array}$ & $\begin{array}{l}\text { Open-label } \\
\text { trial }\end{array}$ & $\begin{array}{l}\text { High risk pregnant patients with APS or } \\
\text { SLE } \\
\text { (target sample size: } 50)\end{array}$ & $\begin{array}{l}\text { CTZ + LDA + LMWH. } \\
\text { Endpoint: } \\
\text { 1) rate of APOs in women with clinical APS and LAC, and } \\
\text { 2) alterations in angiogenic markers of poor placental } \\
\text { vascularization }\end{array}$ \\
\hline
\end{tabular}

$a P L$ antiphospholipid antibodies, $A P O s$ adverse pregnancy outcomes, $A P S$ anti-phospholipid syndrome, $C T Z$ certolizumab pegol, $H C Q$ hydroxychloroquine, HYPATIA HYdroxychloroquine to improve Pregnancy outcome in women with AnTIphospholipid Antibodies, IMPACT IMProve pregnancy in APS with Certolizumab Therapy, IUGR intrauterine grow restriction, $L D A$ low-dose aspirin, $L M W H$ low molecular heparin, $P D N$ prednisolone, $P E$ pre-eclampsia, $\operatorname{Pr} L$ pregnancy losses, $R C T$ randomized clinical trial, $R S A$ recurrent secondary abortion, $S L E$ systemic lupus erythematosus

LMWH (at week 36-37) should switch to UFH and stop 4-6 h prior to elective induction of delivery, cesarean section, or neuraxial anesthesia [85]. However, if the patient is maintained on prophylacticltherapeutic LMWH, this should be suspended $24 \mathrm{~h}$ prior to elective induction of delivery, cesarean section, or neuraxial anesthesia.

\section{Catastrophic APS}

A special attention should be given to a rare and lifethreatening condition of APS called catastrophic antiphospholipid syndrome (CAPS) that can develop in women during pregnancy [106]. The current management remains challenging and consists as first-line therapy: (1) anticoagulation, (2) pulse of corticosteroids, and/or (3) plasmapheresis, and/or (4) IVIG infusions [106]. In severe cases of CAPS refractory to multiple treatments, current literature reports successful cases using a second-line therapy with rituximab or eculizumab. The latter has been suggested in several recent reports as a second-line treatment option in APS and CAPS [106, 107], and recent data has shown that only trace amounts of eculizumab passes the placenta [108•].

\section{Associated Autoimmune Diseases in aPL/APS Women}

The treatment of patients with ob-APS associated to other autoimmune diseases should include HCQ in association to LDA and prophylactic or therapeutic heparin depending on the clinical (with or without previous thrombosis) and laboratory (low- vs high-risk) profile [80••]. It is still unknown the risk of obstetric complications in aPL carriers, women positive for aPL but without obstetric and thrombotic manifestations of APS, or in women with obstetric morbidity not fulfilling criteria for APS. Considering the pathogenic role of the aPL, a stratification risk should be taken into account based on the same risk factors mentioned above for definite ob-APS.

To date, few studies have been investigated the risk of APOs in these women making it difficult to draw 
conclusions given the heterogeneity of type and number of aPL tested [59•, 109-111]. LDA, also used in women without aPL for the prevention of PE [112], has not been shown to have efficacy as primary prophylaxis in reducing APOs in aPL carriers; but this systematic review included only five studies involving 154 pregnancies [113]. However, in clinical practice, LDA is generally used to manage aPL carriers during pregnancy, especially if one or two fetal losses or maternal risk factors are present [114]. In a large retrospective observational study, the rate of pregnancy losses, gestational weight at delivery, and birth weight percentile was not different between aPL positive women treated with LDA and those not treated [109]. The same data was confirmed in another large cohort of 73 pregnant aPL carriers (mostly isolated LA) [110]. More recently, in a multicenter study, among 200 pregnant women positive for aPL, aPL carriers experienced a similar number of APOs compared to ob-APS (18\%) and thrombotic APS (24\%); triple aPL positivity was associated to APOs even in aPL carriers on treatment with LDA plus LMWH [60]. In another multicenter study [111], APOs were observed in 9\% of aPL carriers and were associated to acquired traditional risk factors, "APS non-criteria" or "lupus-like" manifestations and triple aPL positivity. Interestingly, APOs occurred despite combination treatment with LDA and prophylactic LMWH, suggesting that aPL carriers with multiple risk factors and a "high-risk" aPL profile may require additional treatment, such as therapeutic LMWH or HCQ. In the first-year analysis of the European Registry on Obstetric Antiphospholipid Syndrome (EUROAPS), women with obstetric morbidity not fulfilling criteria for APS had APOs similar to those with ob-APS and benefit from the combination therapy with LDA and prophylactic LMWH [78]. The beneficial role of HCQ in pregnant aPL carriers has been hypothesized $[115,116]$, and the RCT HYPATIA will assess the role HCQ in reducing APOs in aPL carriers, too [95].

\section{Perspectives}

Promising results have been observed for novel pharmacological mechanisms that could prevent the binding of either $\beta 2$ GPI or a $\beta 2$ GPI to the trophoblast surface: the binding site of domain $\mathrm{V}$ of $\beta 2 \mathrm{GPI}$ can be targeted by the synthetic peptide TIFI [117]; a non-complement fixing antibody to $\beta 2$ GPI domain 1 can prevent the binding between aPL and $\beta 2$ GPI [118]; the ob-APS phenotype can be attenuated by the induction of tolerogenic dendritic cells specific for $\beta 2$ GPI domain 1 [119]; and the binding site of $\beta 2$ GPI to its receptors can be inhibited by the 1N11 monoclonal antibody [120].

\section{Conclusions}

Besides thrombotic microangiopathy, new pathogenic pathways involving uncontrolled inflammation support the development of poor pregnancy outcomes. Further studies are required to deepen our understanding of how aPL cause ob-APS and to clarify the epidemiology of ob-APS and its different subsets. The current treatment regimen to prevent obstetric morbidity in APS is based on LDA and heparin; this approach has improved pregnancy outcomes to a live birth rate of over $70 \%$. As nearly $30 \%$ of women continue to have pregnancy complications, further studies are ongoing to assess different options in order to improve pregnancy outcomes in women with APS, especially in refractory ob-APS and aPL carriers. HCQ seems to be a promising drug, based on experimental and clinical studies. Other drugs interacting with the pathogenic mechanisms of ob-APS such as eculizumab and statins could be considered in selected complex cases.

\section{Compliance with Ethical Standards}

Conflict of Interest The authors declare that they have no conflict of interest.

Human and Animal Rights and Informed Consent This article does not contain any studies with human or animal subjects performed by any of the authors.

\section{References}

Papers of particular interest, published recently, have been highlighted as:

- Of importance

•- Of major importance

1. Miyakis S, Lockshin MD, Atsumi T, Branch DW, Brey RL, Cervera R, et al. International consensus statement on an update of the classification criteria for definite antiphospholipid syndrome (APS). J Thromb Haemost. 2006;4(2):295-306.

2. Meroni PL, Raschi E, Grossi C, Pregnolato F, Trespidi L, Acaia B, et al. Obstetric and vascular APS: same autoantibodies but different diseases? Lupus. 2012;21(7):708-10.

3. Galarza-Maldonado C, Kourilovitch MR, Pérez-Fernández OM, Gaybor M, Cordero C, Cabrera S, et al. Obstetric antiphospholipid syndrome. Autoimmun Rev. 2012;11(4):288-95.

4. Poulton K, Ripoll VM, Pericleous C, Meroni PL, Gerosa M, Ioannou Y, et al. Purified IgG from patients with obstetric but not IgG from non-obstetric antiphospholipid syndrome inhibit trophoblast invasion. Am J Reprod Immunol. 2015;73(5):390-401.

5. D'Ippolito S, Meroni PL, Koike T, Veglia M, Scambia G, Di Simone N. Obstetric antiphospholipid syndrome: a recent classification for an old defined disorder. Autoimmun Rev. 2014;13(9):901-8.

6. Le Thi Thuong D. The HELLP syndrome in the antiphospholipid syndrome: retrospective study of 16 cases in 15 women. Ann Rheum Dis [Internet]. 2005;64(2):273-8.

7. Cervera R, Piette JC, Font J, Khamashta MA, Shoenfeld Y, Camps MT, et al. Antiphospholipid syndrome: clinical and immunologic 
manifestations and patterns of disease expression in a cohort of 1 , 000 patients. Arthritis Rheum. 2002;46(4):1019-27.

8. Andreoli L, Chighizola CB, Banzato A, Pons-Estel GJ, De Jesus GR, Erkan D. Estimated frequency of antiphospholipid antibodies in patients with pregnancy morbidity, stroke, myocardial infarction, and deep vein thrombosis: a critical review of the literature. Arthritis Care Res. 2013;65(11):1869-73.

9. Sacharidou A, Shaul P, Mineo C. New insights in the pathophysiology of antiphospholipid syndrome. Semin Thromb Hemost. 2017; https://doi.org/10.1055/s-0036-1597286. [Epub ahead of print]

10. Meroni PL, Borghi MO, Raschi E, Tedesco F. Pathogenesis of antiphospholipid syndrome: understanding the antibodies. Nat Rev Rheumatol. 2011;7(6):330-9.

11. De Wolf F, Carreras LO, Moerman P, Vermylen J, Van Assche ARM. Decidual vasculopathy and extensive placental infarction in a patient with repeated thromboembolic accidents, recurrent fetal loss, and a lupus anticoagulant. Am J Obs Gynecol. 1982;142(7):829-34

12. Stone S, Pijnenborg R, Vercruysse L, Poston R, Khamashta MA, Hunt BJ, et al. The placental bed in pregnancies complicated by primary antiphospholipid syndrome. Placenta. 2006;27(4-5):45767.

13. Rand JH, Wu XX, Quinn AS, Ashton AW, Chen PP, Hathcock JJ, et al. Hydroxychloroquine protects the annexin A5 anticoagulant shield from disruption by antiphospholipid antibodies: evidence for a novel effect for an old antimalarial drug. Blood. 2010;115(11):2292-9.

14. Ramesh S, Morrell CN, Tarango C, Thomas GD, Yuhanna IS, Girardi G, et al. Antiphospholipid antibodies promote leukocyteendothelial cell adhesion and thrombosis in mice by antagonizing eNOS via $\beta 2$ GPI and apoER2. J Clin Invest. 2011;121(1):120 31.

15. Espinola RG, Liu X, Colden-Stanfield M, Hall J, Harris EN, Pierangeli SS. E-Selectin mediates pathogenic effects of antiphospholipid antibodies. J Thromb Haemost. 2003;1(4):8438 .

16. Vega-Ostertag ME, Ferrara DE, Romay-Penabad Z, Liu X, Taylor WR, Colden-Stanfield M, et al. Role of p38 mitogen-activated protein kinase in antiphospholipid antibody-mediated thrombosis and endothelial cell activation. J Thromb Haemost. 2007;5(9): 1828-34.

17. Romay-Penabad Z, Aguilar-Valenzuela R, Urbanus RT, Derksen RH, Pennings MT, Papalardo E, et al. Apolipoprotein E receptor 2 is involved in the thrombotic complications in a murine model of the antiphospholipid syndrome. Blood. 2011;117(4):1408-14.

18. Giannakopoulos B, Passam F, Rahgozar S, Krilis SA. Current concepts on the pathogenesis of the antiphospholipid syndrome. Blood. 2007;109(2):422-30.

19. Urbanus RT, Pennings MT, Derksen RH, de Groot PG. Platelet activation by dimeric beta2-glycoprotein I requires signaling via both glycoprotein I b alpha and apolipoprotein $\mathrm{E}$ receptor $2^{\prime}$. J Thromb Haemost. 2008;6(8):1405-12.

20. Krone KA, Allen KL, McCrae KR. Impaired fibrinolysis in the antiphospholipid syndrome. Curr Rheumatol Rep. 2010;12(1):537.Krone 2010.

21. Yang YH, Chang CJ, Chuang YH, Hsu HY, Chen PP, Chiang BL. Identification of anti-prothrombin antibodies in the antiphospholipid syndrome that display the prothrombinase activity. Rheumatology (Oxford). 2010;49(1):34-42.

22. Fischetti F, Durigutto P, Pellis V, Debeus A, Macor P, Bulla R, et al. Thrombus formation induced by antibodies to beta2glycoprotein $\mathrm{I}$ is complement dependent and requires a priming factor. Blood. 2005;106(7):2340-6.

23. Pierangeli SS, Vega-Ostertag ME, Raschi E, Liu X, RomayPenabad Z, De Micheli V, et al. Toll-like receptor and antiphospholipid mediated thrombosis: in vivo studies. Ann Rheum Dis. 2007;66(10):1327-33.

24. Mulla MJ, Brosens JJ, Chamley LW, Giles I, Pericleous C, Rahman A, et al. Antiphospholipid antibodies induce a proinflammatory response in first trimester trophoblast via the TLR4/MyD88 pathway. Am J Reprod Immunol. 2009;62(2):96111.

25. Mulla MJ, Salmon JE, Chamley LW, Brosens JJ, Boeras CM, Kavathas PB, et al. A role for uric acid and the Nalp3 inflammasome in antiphospholipid antibody-induced IL- $1 \beta$ production by human first trimester trophoblast. PLoS One. 2013;8(6):2-9.

26. Chighizola CB, Pregnolato F, Raschi E, Grossi C, Gentilini D, Borghi MO, et al. Antiphospholipid antibodies and infertility: a gene expression study in decidual stromal cells. Isr Med Assoc J. 2016;18(3-4):146-9.

27. Ulrich V, Gelber SE, Vukelic M, Sacharidou A, Herz J, Urbanus RT de GP, Natale DR, Harihara A, Redecha P, Abrahams VM, Shaul PW, Salmon JE MC. ApoE receptor 2 mediation of trophoblast dysfunction and pregnancy complications induced by antiphospholipid antibodies in mice. Arthritis Rheumatol. 2016;68(3):730-9.

28. Girardi G, Berman J, Redecha P, Spruce L, Thurman JM, Kraus D, et al. Complement $\mathrm{C} 5 \mathrm{a}$ receptors and neutrophils mediate fetal injury in the antiphospholipid syndrome. J Clin Invest. 2003;112(11):1644-54. Erratum in: J Clin Invest. 2004;113(4): 646.

29. Redecha P, Franzke CW, Ruf W, Mackman N, Girardi G. Neutrophil activation by the tissue factor/factor VIIa/PAR2 axis mediates fetal death in a mouse model of antiphospholipid syndrome. J Clin Invest. 2008;118(10):3453-61.

30. Redecha P, Franzke CW, Ruf W, Mackman N, Girardi G. Neutrophil activation by the tissue factor/factor VIIa/PAR2 axis mediates fetal death in a mouse model of antiphospholipid syndrome. J Clin Invest. 2008;118(10):3453-61.

31. Seshan SV, Franzke CW, Redecha P, Monestier M, Mackman N, Girardi G. Role of tissue factor in a mouse model of thrombotic microangiopathy induced by antiphospholipid antibodies. Blood. 2009;114(8):1675-83.

32. Thurman JM, Kraus DM, Girardi G, Hourcade D, Kang HJ, Royer PA, et al. A novel inhibitor of the alternative complement pathway prevents antiphospholipid antibody-induced pregnancy loss in mice. Mol Immunol. 2005;42(1):87-97.

33. Girardi G, Yarilin D, Thurman JM, Holers VM, Salmon JE. Complement activation induces dysregulation of angiogenic factors and causes fetal rejection and growth restriction. J Exp Med. 2006;203(9):2165-75.

34. Pierangeli SS, Girardi G, Vega-Ostertag M, Liu X, Espinola RG, Salmon J. Requirement of activation of complement C3 and C5 for antiphospholipid antibody-mediated thrombophilia. Arthritis Rheum. 2005;52(7):2120-4.

35. Shamonki JM, Salmon JE, Hyjek E, Baergen RN. Excessive complement activation is associated with placental injury in patients with antiphospholipid antibodies. Am J Obstet Gynecol. 2007;196(2):1-5.

36. Viall CA, Chamley LW. Histopathology in the placentae of women with antiphospholipid antibodies: a systematic review of the literature. Autoimmun Rev. 2015;14(5):446-71.

37.• Viall CA, Chen Q, Liu B, Hickey A, Snowise S, Salmon JE, et al. Antiphospholipid antibodies internalised by human syncytiotrophoblast cause aberrant cell death and the release of necrotic trophoblast debris. J Autoimmun. 2013;47:45-57. This systematic review offers a clear picture of the histopathological features found in the placentae of aPL-positive women. 
38. Viall CA, Chen Q, Stone PR, Chamley LW. Human extravillous trophoblasts bind but do not internalize antiphospholipid antibodies. Placenta. 2016;42:9-16.

39. Burton GJ. Deportation of syncytial sprouts from the term human placenta. Placenta. 2011;32(1):96-8.

40. Verlohren S, Geusens N, Morton J, Verhaegen I, Hering L, Herse $\mathrm{F}$, et al. Inhibition of trophoblast-induced spiral artery remodeling reduces placental perfusion in rat pregnancy. Hypertension. 2010;56(2):304-10.

41. Carroll TY, Mulla MJ, Han CS, Brosens JJ, Chamley LW, Giles I, et al. Modulation of trophoblast angiogenic factor secretion by antiphospholipid antibodies is not reversed by heparin. Am J Reprod Immunol. 2011;66(4):286-96.

42. Alvarez AM, Mulla MJ, Chamley LW, Cadavid AP, Abrahams VM. Aspirin-triggered lipoxin prevents antiphospholipid antibody effects on human trophoblast migration and endothelial cell interactions. Arthritis Rheumatol. 2015;67(2):488-97.

43. Gysler SM, Mulla MJ, Guerra M, Brosens JJ, Salmon JE, Chamley LW, et al. Antiphospholipid antibody-induced miR146a-3p drives trophoblast interleukin-8 secretion through activation of Toll-like receptor 8. Mol Hum Reprod. 2016;22(7):46574.

44. Mulla MJ, Weel IC, Potter JA, Gysler SM, Salmon JE, Perac MTS, et al. Antiphospholipid antibodies inhibit trophoblast Tolllike receptor and inflammasome negative regulators. 2018; https:// doi.org/10.1002/art.40416. This study showed for the first time that aPL pass over negative regulators of placental trophoblast TLR and inflammasome signaling to induce a robust inflammatory response.

45. Bose P, Black S, Kadyrov M, Bartz C, Shlebak A, Regan L, Huppertz B. Adverse effects of lupus anticoagulant positive blood sera on placental viability can be prevented by heparin in vitro. Am J Obstet Gynecol. 2004;191(6):2125-31.

46. Salmon JE, Heuser C, Triebwasser M, Liszewski MK, Kavanagh $\mathrm{D}$, Roumenina L, et al. Mutations in complement regulatory proteins predispose to preeclampsia: a genetic analysis of the PROMISSE cohort. PLoS Med. 2011;8(3):1-9.

47. Kim MY, Guerra MM, Kaplowitz E, Laskin CA, Petri M, Branch DW, et al. Complement activation predicts adverse pregnancy outcome in patients with systemic lupus erythematosus and/or antiphospholipid antibodies. Ann Rheum Dis. 2018;77(4):549-55.

The PROMISSE Study showed that increased complement activation early in pregnancy is strongly predictive of adverse pregnancy outcomes in pregnant patients with SLE and/or aPL.

48. Abrahams VM, Chamley LW, Salmon JE. Emerging treatment models in rheumatology: antiphospholipid syndrome and pregnancy: pathogenesis to translation. Arthritis Rheumatol. 2017;69(9):1710-21.

49. Alijotas-Reig J, Esteve-Valverde E, Ferrer-Oliveras R, Llurba E, Gris JM. Tumor necrosis factor-alpha and pregnancy: focus on biologics. An updated and comprehensive review. Clin Rev Allergy Immunol. 2017;53(1):40-53.

50. Salafia CMCF. Placental pathology and antiphospholipid antibodies: a descriptive study. Am J Perinatol. 1997;14(8):435-41.

51. Sebire NJ. Defective endovascular trophoblast invasion in primary antiphospholipid antibody syndrome-associated early pregnancy failure. Hum Reprod. 2002;17(4):1067-71.

52. Andrade D, Kim M, Blanco LP, Karumanchi SA, Koo GC, Redecha $\mathrm{P}$, et al. Interferon- $\alpha$ and angiogenic dysregulation in pregnant lupus patients who develop preeclampsia. Arthritis Rheumatol. 2015;67(4):977-87.

53. Jeremic K, Stefanovic A, Dotlic J, Stojnic J, Kadija S, Vilendecic $Z$, et al. Neonatal outcome in pregnant patients with antiphospholipid syndrome. J Perinat Med. 2015;43(6):761-8.
54. Rezk M, Dawood R, Badr H. Maternal and fetal outcome in women with antiphospholipid syndrome: a three-year observational study. J Matern Neonatal Med. 2016;29(24):4015-9.

55. Ruffatti A, Salvan E, Del Ross T, Gerosa M, Andreoli L, Maina A, et al. Treatment strategies and pregnancy outcomes in antiphospholipid syndrome patients with thrombosis and triple antiphospholipid positivity: a European multicentre retrospective study. Thromb Haemost. 2014;112(4):727-35.

56. Ruffatti A, Tonello M, Visentin MS, Bontadi A, Hoxha A, De Carolis S, et al. Risk factors for pregnancy failure in patients with anti-phospholipid syndrome treated with conventional therapies: a multicentre, case-control study. Rheumatology. 2011;50(9):1684-9.

57. De Carolis S, Botta A, Santucci S, Garofalo S, Martino C, Perrelli A, et al. Predictors of pregnancy outcome in antiphospholipid syndrome: a review. Clin Rev Allergy Immunol. 2010;38(2-3):116-24.

58. Deguchi M, Yamada H, Sugiura-Ogasawara M, Morikawa M, Fujita D, Miki A, et al. Factors associated with adverse pregnancy outcomes in women with antiphospholipid syndrome: a multicenter study. J Reprod Immunol. 2017;122:21-7.

59. Fredi M, Andreoli L, Aggogeri E, Bettiga E, Grazia M, Le GV, et al. Risk factors for adverse maternal and fetal outcomes in women with con firmed aPL positivity: results from a multicenter study of 283 pregnancies. 2018;9(May):1-8. A large multicenter study of nearly 300 pregnancies in women with aPL, showing for the first time that patients with no definite ob-APS ("aPL carriers") are at risk of adverse pregnancy outcomes according to their aPL profile (triple aPL positivity).

60. Simchen MJ, Dulitzki M, Rofe G, Shani H, Langevitz P, Schiff E, et al. High positive antibody titers and adverse pregnancy outcome in women with antiphospholipid syndrome. Acta Obstet Gynecol Scand. 2011;90(12):1428-33.

61. Latino JO, Udry S, Aranda FM, Perés Wingeyer SDA, Fernández Romero DS, De Larrañaga GF. Pregnancy failure in patients with obstetric antiphospholipid syndrome with conventional treatment: the influence of a triple positive antibody profile. Lupus. 2017;26(9):983-8.

62. Saccone G, Berghella V, Maruotti GM, Ghi T, Rizzo G, Simonazzi $\mathrm{G}$, et al. Antiphospholipid antibody profile based obstetric outcomes of primary antiphospholipid syndrome: the PREGNANTS study. Am J Obstet Gynecol. 2017;216(5): 525.e1-525.e12.

63. Forastiero R, Martinuzzo M. The emerging role of multiple antiphospholipid antibodies positivity in patients with antiphospholipid syndrome. Expert Rev Clin Immunol. 2015;11(11):1255-63.

64. Banzato A, Pozzi N, Frasson R, De Filippis V, Ruffatti A, Bison E, et al. Antibodies to domain I of $\beta(2)$ glycoprotein I are in close relation to patients risk categories in antiphospholipid syndrome (APS). Thromb Res. 2011;128(6):583-6.

65. de Laat B, Derksen RH, Urbanus RT de GP. IgG antibodies that recognize epitope Gly40-Arg43 in domain I of beta 2-glycoprotein I cause LAC, and their presence correlates strongly with thrombosis. Blood. 2005;105(4):1540-5.

66. Pengo V, Ruffatti A, Tonello M, Hoxha A, Bison E, Denas G, et al. Antibodies to domain 4/5 (Dm4/5) of $\beta 2$-glycoprotein 1 ( $\beta 2 \mathrm{GP} 1$ ) in different antiphospholipid (aPL) antibody profiles. Thromb Res. 2015;136(1):161-3.

67. Chighizola CB, Pregnolato F, Andreoli L, Bodio C, Cesana L, Comerio CG, et al. Beyond thrombosis: anti- $\beta 2$ GPI domain 1 antibodies identify late pregnancy morbidity in antiphospholipid syndrome. $\mathrm{J}$ Autoimmun. 2018;90:76-83. This is the first study to specifically characterize the domain profiling of anti-beta2GPI antibodies in relation to different manifestations of aPL-related pregnancy morbidity.

68. Yelnik CM, Laskin CA, Porter TF, Branch DW, Buyon JP, Guerra MM, et al. Lupus anticoagulant is the main predictor of adverse 
pregnancy outcomes in aPL-positive patients: validation of PROMISSE study results. Lupus Sci Med. 2016;3(1):e000131.

69. Boffa MC, Boinot C, De Carolis S, Rovere-Querini P, Aurousseau $\mathrm{MH}$, Allegri F, et al. Laboratory criteria of the obstetrical antiphospholipid syndrome: data from a multicentric prospective European women cohort. Thromb Haemost. 2009;102(1):25-8.

70. Gardiner C, Hills J, Machin S, Cohen H. Diagnosis of antiphospholipid syndrome in routine clinical practice. Lupus. 2013;22(1):18-25.

71. Ofer-Shiber S, Molad Y. Frequency of vascular and pregnancy morbidity in patients with low vs. moderate-to-high titers of antiphospholipid antibodies. Blood Coagul Fibrinolysis. 2015;26(3):261-6.

72. Chighizola CB, Andreoli L, De Jesus GR, Banzato A, Pons-Estel GJ, Erkan D. The association between antiphospholipid antibodies and pregnancy morbidity, stroke, myocardial infarction, and deep vein thrombosis: a critical review of the literature. Lupus. 2015;24(9):980-4.

73. Chighizola CB, Raimondo MG, Comerio C, Pregnolato F, Sobrino C, Trespidi L, Acaia B, Gerosa M, Ossola W MP. The risk of obstetric complications and the effects of treatment in women with low titer and medium-high titer anti-phospholipid antibodies. Arthritis Rheumatol. 2016;68(suppl 10).

74. De Jesus GR, Agmon-Levin N, Andrade CA, Andreoli L, Chighizola CB, Flint Porter T, et al. 14th international congress on antiphospholipid antibodies task force report on obstetric antiphospholipid syndrome. Autoimmun Rev. 2014;13(8):795813.

75. Mekinian A, Loire-Berson P, Nicaise-Roland P, Lachassinne E, Stirnemann J, Boffa MC, et al. Outcomes and treatment of obstetrical antiphospholipid syndrome in women with low antiphospholipid antibody levels. J Reprod Immunol. 2012;94(2): $222-6$.

76. Lockshin MD, Kim M, Laskin CA, Guerra M, Branch DW, Merrill J, et al. Prediction of adverse pregnancy outcome by the presence of lupus anticoagulant, but not anticardiolipin antibody, in patients with antiphospholipid antibodies. Arthritis Rheum. 2012;64(7):2311-8.

77.• Cervera R, Serrano R, Pons-Estel GJ, Ceberio-Hualde L, Shoenfeld Y, De Ramón E, et al. Morbidity and mortality in the antiphospholipid syndrome during a 10-year period: a multicentre prospective study of 1000 patients. Ann Rheum Dis. 2015;74(6): 1011-8. This paper reports the data of the Euro-Phospholipid project, a prospective observational study of a cohort of 1000 European APS patients with a 10-year follow up.

78. Alijotas-Reig J, Ferrer-Oliveras R, Ruffatti A, Tincani A, Lefkou E, Bertero MT, et al. The European registry on obstetric antiphospholipid syndrome (EUROAPS): a survey of 247 consecutive cases. Autoimmun Rev. 2015;14(5):387-95.

79. Drozidnsky G, Hadar E, Shmueli A, Gabbay-Benziv R, Shiber S. Obstetric antiphospholipid syndrome and long term arterial thrombosis risk. J Thromb Thrombolysis. 2017;44(3):1-5.

80.• Andreoli L, Bertsias GK, Agmon-Levin N, Brown S, Cervera R, Costedoat-Chalumeau N, et al. EULAR recommendations for women's health and the management of family planning, assisted reproduction, pregnancy and menopause in patients with systemic lupus erythematosus and/or antiphospholipid syndrome. Ann Rheum Dis. 2017;76(3):476-85. EULAR recommendations based on systematic literature review and expert opinion regarding the management of family planning, pregnancy and women's health issues in SLE and/or APS patients.

81. Keeling D, Mackie I, Moore GW, Greer IA, Greaves M. Guidelines on the investigation and management of antiphospholipid syndrome. Br J Haematol. 2012;157(1):47-58.

82. Triolo G, Ferrante A, Ciccia F, Accardo-Palumbo A, Perino A, Castelli A, et al. Randomized study of subcutaneous low molecular weight heparin plus aspirin versus intravenous immunoglobulin in the treatment of recurrent fetal loss associated with antiphospholipid antibodies. Arthritis Rheum. 2003;48(3):72831.

83. Fouda UM, Sayed AM, Abdou AMA, Ramadan DI, Fouda IM, Zaki MM. Enoxaparin versus unfractionated heparin in the management of recurrent abortion secondary to antiphospholipid syndrome. Int J Gynecol Obstet. 2011;112(3):211-5.

84. Empson M, Lassere M, Craig JSJ. Prevention of recurrent miscarriage for women with antiphospholipid antibody or lupus anticoagulant. Cochrane Database Syst Rev. 2005;2:CD002859.

85. Marshall AL. Diagnosis, treatment, and prevention of venous thromboembolism in pregnancy. Postgrad Med. 2014;126(7):2534.

86. Mekinian A, Alijotas-Reig J, Carrat F, Costedoat-Chalumeau N, Ruffatti A, Lazzaroni MG, et al. Refractory obstetrical antiphospholipid syndrome: features, treatment and outcome in a European multicenter retrospective study. Autoimmun Rev. 2017;16(7):730-4.

87. Ruffatti A, Tonello M, Hoxha A, Sciascia S, Cuadrado MJ, Latino JO, et al. Effect of additional treatments combined with conventional therapies in pregnant patients with high-risk antiphospholipid syndrome: a multicentre study. Thromb Haemost. 2018;118(4):639-46. This multicenter international study compares the effects of different treatments administered in addition to conventional therapy to a large cohort of pregnant APS patients refractory to conventional therapy and/or at high risk of pregnancy complications.

88. Sciascia S, Branch DW, Levy RA, Middeldorp S, Pavord S, Roccatello D, et al. The efficacy of hydroxychloroquine in altering pregnancy outcome in women with antiphospholipid antibodies: evidence and clinical judgment. Thromb Haemost. 2016;115(2): 285-90.

89. Erkan D, Aguiar CL, Andrade D, Cohen H, Cuadrado MJ, Danowski A, et al. 14th international congress on antiphospholipid antibodies task force report on antiphospholipid syndrome treatment trends. Autoimmun Rev. 2014;13(6):685-96.

90. Wu XX, Guller SRJ. Hydroxychloroquine reduces binding of antiphospholipid antibodies to syncytiotrophoblasts and restores annexin A5 expression. Am J Obs Gynecol. 2011;205(6):576.e714.

91. Bertolaccini ML, Contento G, Lennen R, Sanna G, Blower PJ, Ma MT, et al. Complement inhibition by hydroxychloroquine prevents placental and fetal brain abnormalities in antiphospholipid syndrome. J Autoimmun. 2016;75:30-38. In a mouse model of obstetric APS, hydroxychloroquine was able to prevent fetal death and the placental metabolic changes, and prevented complement activation in vivo and in vitro, possibly suggesting for the first time that this drug can be helpful in preventing abnormal fetal brain development.

92. Mekinian A, Lazzaroni MG, Kuzenko A, Alijotas-Reig J, Ruffatti A, Levy P, et al. The efficacy of hydroxychloroquine for obstetrical outcome in anti-phospholipid syndrome: data from a European multicenter retrospective study. Autoimmun Rev. 2015;14(6): 498-502.

93. Sciascia S, Hunt BJ, Talavera-Garcia E, Lliso G, Khamashta MA $\mathrm{CM}$. The impact of hydroxychloroquine treatment on pregnancy outcome in women with antiphospholipid antibodies. 2016;214: 273.e1-273.e8.

94. Ye S-L, Gu X-K, Tao L-Y, Cong J-M, Wang Y-Q. Efficacy of different treatment regimens for antiphospholipid syndromerelated recurrent spontaneous abortion. Chin Med J. 2017;130(12):1395.

95. Karen S, Karen B, Cohen Hannah JS. Hydroxichloroquine to improve pregnancy outcome in women with antiphospholipid antibodies (HYPATIA) protocol: a multinational randomized 
controlled trial of hydroxichloroquine versus placebo in addition to standard treatment in pregnant women with antipho. Semin Thromb Homeost. 2017;43:562-71.

96. Mekinian A, Vicaut E, Cohen J, Bornes M, Kayem G, Fain O. Hydroxychloroquine to obtain pregnancy without adverse obstetrical events in primary antiphospholipid syndrome: French phase II multicenter randomized trial, HYDROSAPL. Gynecol Obstet Fertil Senol. 2018;46(7-8):598-604.

97. Lefkou E, Mamopoulos A, Dagklis T, Vosnakis C, Rousso DGG. Pravastatin improves pregnancy outcomes in obstetric antiphospholipid syndrome refractory to antithrombotic therapy. $\mathrm{J}$ Clin Invest, This is the first study to suggests that pravastatin may improve pregnancy outcomes in women with refractory ob-APS when taken at the onset of PE or IUGR until the end of pregnancy. 2016;126(8):2933-40.

98. Mariette X, Förger F, Abraham B, Flynn AD, Moltó A, Flipo RM, et al. Lack of placental transfer of certolizumab pegol during pregnancy: results from CRIB, a prospective, postmarketing, pharmacokinetic study. Ann Rheum Dis. 2018;77(2):228-33.

99. IMPACT study:IMProve Pregnancy in APS With Certolizumab Therapy [Internet]. [cited 2018 May 17]. Available from: https:// clinicaltrials.gov/ct2/show/NCT03152058

100. da Silva SS, de Moraes MB, Quinteiro Tobaldine LP, Colella M, Vinícius De Paula E, Annichinno-Bizzachi J, et al. The impact of antibody profile in thrombosis associated with primary antiphospholipid syndrome. Am J Hematol. 2017;92:1163-9.

101. Chighizola CB, Andreoli L, Gerosa M, Tincani A, Ruffatti A, Meroni PL. The treatment of anti-phospholipid syndrome: a comprehensive clinical approach. J Autoimmun. 2018;90:1-27.

102. Bates SM, Greer IA, Middeldorp S, Veenstra DL, Prabulos A-M, Vandvik PO. VTE, thrombophilia, antithrombotic therapy, and pregnancy. Chest. 2012;141(2):e691S-736S.

103. Sousa A, Barreira R, Santos E. Low-dose warfarin maternal anticoagulation and fetal warfarin syndrome. BMJ Case Rep. 2018;pii: bcr-2017-223159.

104. Basu S, Aggarwal P, Kakani N, Kumar A. Low-dose maternal warfarin intake resulting in fetal warfarin syndrome: in search for a safe anticoagulant regimen during pregnancy. Birth Defects Res Part A - Clin Mol Teratol. 2016;106(2):142-7.

105. Danowski A, Rego J, Kakehasi AM, Funke A, de Carvalho JF, Lima IVS, et al. Guidelines for the treatment of antiphospholipid syndrome. Rev Bras Reumatol (English Ed [Internet]. 2013;53(2):184-92.

106. Rodríguez-Pintó I, Moitinho M, Santacreu I, Shoenfeld Y, Erkan D, Espinosa G, et al. Catastrophic antiphospholipid syndrome (CAPS): descriptive analysis of 500 patients from the international CAPS registry. Autoimmun Rev. 2016;15(12):1120-4.

107. Barratt-Due A, Fløisand Y, Orrem HL, Kvam AK, Holme PA, Bergseth G, et al. Complement activation is a crucial pathogenic factor in catastrophic antiphospholipid syndrome. Rheumatology (Oxford). 2016;55(7):1337-9.

108. Gustavsen A, Skattum L, Bergseth G, Lorentzen B, Floisand Y, Bosnes V, et al. Effect on mother and child of eculizumab given before caesarean section in a patient with severe antiphospholipid syndrome: a case report. Medicine (Baltimore) [internet]. 2017;96(11):e6338. This is the first study to demonstrate that only trace amounts of eculizumab cross the placenta and this drug can be considered as an effective treatment for APS pregnant patients presenting with life-threatening conditions such as CAPS.

109. Del Ross T, Ruffatti A, Visentin MS, Tonello M, Calligaro A, Favaro M, et al. Treatment of 139 pregnancies in antiphospholipidpositive women not fulfilling criteria for antiphospholipid syndrome: a retrospective study. J Rheumatol. 2013;40(4):425-9.

110. Soh MC, Pasupathy D, Gray G, Nelson-Piercy C. Persistent antiphospholipid antibodies do not contribute to adverse pregnancy outcomes. Rheumatol (United Kingdom). 2013;52(9):1642-7.

111. Lazzaroni MG, Andreoli L, Chighizola CB, Del Ross T, Gerosa M, Kuzenko A, Raimondo MG, Lojacono A, Zatti S, Ramazzotto F, Trespidi L, Meroni PL, Pengo V, Ru atti A TA. Risk factors for adverse pregnancy outcome in antiphospholipid antibodies carriers: results from a multicenter Italian cohort over 20 years of experience. Arthritis Rheumatol. 2016;68 (suppl 10).

112. Roberge S, Villa P, Nicolaides K, et al. Early administration of low-dose aspirin for the prevention of preterm and term preeclampsia: a systematic review and meta-analysis. Fetal Diagn Ther. 2012;31(3):141-6.

113. Amengual O, Fujita D, Ota E, Carmona L, Oku K, SugiuraOgasawara MM, et al. Primary prophylaxis to prevent obstetric complications in asymptomatic women with antiphospholipid antibodies: a systematic review. Lupus. 2015 Oct;24(11):1135-42. Lupus. 2015;24(11):1135-42.

114. Erkan D, Patel S, Nuzzo M, Gerosa M, Meroni PL, Tincani A, et al. Management of the controversial aspects of the antiphospholipid syndrome pregnancies: a guide for clinicians and researchers. Rheumatology. 2008;47(Supplement 3):iii23-7.

115. Meroni PL. Prevention \& treatment of obstetrical complications in APS: is hydroxychloroquine the Holy Grail we are looking for? J Autoimmun. 2016;75:1-5.

116. Abd Rahman R, DeKoninck P, Murthi P, Wallace EM. Treatment of preeclampsia with hydroxychloroquine: a review. J Matern Neonatal Med. 2018;31(4):525-9.

117. Di Simone N, D’Ippolito S, Marana R, Di Nicuolo F, Castellani R, Pierangeli SS, et al. Antiphospholipid antibodies affect human endometrial angiogenesis: protective effect of a synthetic peptide (TIFI) mimicking the phospholipid binding site of $\beta 2$ glycoprotein I. Am J Reprod Immunol. 2013;70(4):299-308.

118. Agostinis C, Durigutto P, Sblattero D, Borghi MO, Grossi C, Guida F, et al. A non-complement-fixing antibody to b2 glycoprotein I as a novel therapy for antiphospholipid syndrome. Blood. 2014;123(22):3478-87.

119. Zandman-Goddard G, Pierangeli SS, Gertel S BM. Tolerogenic dendritic cells specific for b2-glycoprotein-I Domain-I, attenuate experimental antiphospholipid syndrome. 2014;54:72-80.

120. Mineo C, Lanier L, Jung E, Sengupta S, Ulrich V, Sacharidou A, et al. Identification of a monoclonal antibody that attenuates antiphospholipid syndrome-related pregnancy complications and thrombosis. PLoS One. 2016;11(7):e0158757. 